\title{
A comparative evaluation of surface water quality standards for lakes and fish ponds from Bucharest and vicinity \\ https://doi.org/10.21698/rjeec.2020.204 \\ Proceedings Paper
}

\section{GINA VASILE SCAETEANU, ROXANA MARIA MADJAR*, MALA-MARIA STAVRESCU-BEDIVAN}

University of Agronomic Sciences and Veterinary Medicine, Faculty of Agriculture, 59 Blvd. Marasti, 011464,

Bucharest, Romania

corresponding author(e-mail): rmadjar@yahoo.com

\begin{abstract}
Monitoring of lakes and ponds water quality parameters is important to evaluate the interactions between quality and effects on aquatic organisms' growth and health. Even if each water parameter individually may not be relevant, several parameters together can reveal dynamic processes that occur in the water. For instance, unbalanced $\mathrm{pH}$ values may increase ammonia and hydrogen sulfide toxicity. Nitrogen and phosphorus are associated with plant and algae growth, although phosphorus is generally the limiting nutrient in freshwater bodies. Accordingly, it is recommended to monitor and assess water quality parameters based on routine analyses. Therefore, this study aimed to generate an overview of our researches related to the monitoring of water quality collected from lakes and fish ponds. The parameters based on which was evaluated the quality of water were: $p H$, electrical conductivity (EC), total hardness (TH), chemical oxygen demand $(\mathrm{COD})$, nitrate nitrogen $\left(\mathrm{N}-\mathrm{NO}_{3}{ }^{-}\right)$, nitrite nitrogen $\left(\mathrm{N}-\mathrm{NO}_{2}{ }^{-}\right)$, ammonium nitrogen $\left(\mathrm{N}-\mathrm{NH}_{4}^{+}\right)$, phosphate phosphorus $\left(\mathrm{P}-\mathrm{PO}_{4}{ }^{3-}\right)$.
\end{abstract}

Keywords: environmental protection, fish, lake, nitrate, nitrite, phosphate

\section{INTRODUCTION}

Nowadays, one of the most challenging environmental problems is eutrophication that is associated with the destruction of lake ecosystems around the world and decreases the value of its use in various urban purposes. According to the literature [1], the mechanisms of water eutrophication are not fully understood but one of the factors involved in this process is considered to be excessive nutrient containing species (nitrogen and phosphorus) loading into surface waters. Dense algal blooms development generates a hypoxic environment that affects aquatic life. The consequences are sustained by drinking water sources, fisheries, and recreational water bodies.

Lakes from Bucharest and vicinity are used for different economical (irrigation, flooding mitigation) and leisure activities (fishing, recreation), so the conservation of these ecosystems is important from the socioecological point of view [2]. As rivers are the receiver of environmental problems resulted from the intake of wastewaters and different residues disposal, the necessity to increase the sewage network coverage and restriction of uncontrolled waste disposal are very important. Studies that evidence this issue were developed for lakes along Colentina River [3] and Dambovita River [4].

As water quality is critical for aquatic life, its monitoring has been documented and reported [5-7]. It has been demonstrated that high nutrient loads can intensify algal blooms, the proliferation of aquatic plant growth, and decomposition meanwhile $\mathrm{SO}_{2}, \mathrm{NO}_{2}$, and $\mathrm{NO}$ are the major acidifying agents in lakes and streams. Accordingly, decreasing the $\mathrm{pH}$ value can increase the concentration of aluminum, zinc, mercury if they are present in lake sediment. Contrariwise, an increase in $\mathrm{pH}$ and temperature generates unionized ammonia levels increase, which is very toxic to aquatic species, especially fish [6].

Considering the importance of water for life and society by sustaining economic growth and prosperity and as a response to the increasing threat of pollution, in 2000 was adopted EU Water Framework Directive (WFD). This Directive establishes a framework for water protection and aims to: expand the scope of water protection to all waters, surface waters, and groundwater, achieve "good status" for all waters by a set 
deadline (December 2015), water management based on river basins, "combined approach" of emission limit values and quality standards [8]. According to WFD, the surface water ecological status includes five categories: high, good, moderate, poor, and bad, each category being color-coded as follows: blue, green, yellow, orange, and red, respectively [9].

The transposition/implementation of WFD into Romanian legislation was achieved by Order $161 / 2006$ for the approval of the Normative concerning the classification of surface water quality to establish the ecological status of water bodies [10]. According to chemical and physical-chemical parameters' values and related to the ecological status, there are

\section{MATERIALS AND METHODS}

The results integrated with this study were previously reported during 2012-2019 for lakes and fish ponds located either in or near Bucharest, as it follows: Cismigiu Lake (CL) [11], Herastrau Lake (HL) [12], Morii Lake (ML) [13], Pantelimon II Lake (PL) [14], Snagov Lake (SL) [15], Branesti Fish Pond (BP) [11], Tataru Fish Pond (TP) [16].

The protocols for sampling and conditioning of water samples, the position of sampling points, and depths may be found in our previously reported results [11-16].

\section{RESULTS AND DISCUSSION}

\section{pH values}

Most freshwater lakes and ponds have $\mathrm{pH}$ values in the range of 6.00-8.00 [17]. Average $\mathrm{pH}$ values for all studied locations (Table 1) are within the recommended range (6.50-8.50) and according to literature; these values may defined five quality classes, $\mathrm{I}^{\text {st }}$ class being associated with the water with the highest quality and very good ecological status.

The paper aims to generate an overview of our previously reported researches [11-16] concerning the monitoring of water quality for lakes and fish ponds from Bucharest and vicinity. Based on chemical and physicochemical parameters, the quality of water was associated with quality classes according to WFD transposed into Order 161/2006 for the approval of the Normative concerning the classification of surface water quality to establish the ecological status of water bodies [10].

The chemical analysis of water samples was performed by using methods similar to those recommended for drinking water, as it follows: potentiometric method (for $\mathrm{pH}$ ), conductometry (for electrical conductivity, EC), complexometry (for total hardness, $\mathrm{TH}$ ), manganometry (for chemical oxygen demand, COD) and spectrophotometry (for nitrate, nitrite, ammonium, phosphate).

be included in the desirable $\mathrm{pH}$ range for optimal growth for most fish species (6.509.50) [18]. Similar results for $\mathrm{pH}$ were reported for Pantelimon II Lake by Ioja and co-workers [3].

Table 1. $\mathrm{pH}$ values for water samples collected from lakes and fish ponds

\begin{tabular}{l|cc}
\hline \multirow{2}{*}{ Location } & \multicolumn{2}{c}{$\mathrm{pH}$} \\
\cline { 2 - 3 } Cismigiu Lake (CL) & Range & Average \\
Herastrau Lake (HL) & $6.53-7.00$ & 6.79 \\
Morii Lake (ML) & $7.68-8.00$ & 7.89 \\
Pantelimon II Lake (PL) & $6.84-8.84$ & 7.47 \\
Snagov Lake (SL) & $6.97-8.19$ & 7.57 \\
Branesti Fish Pond (BP) & $7.70-8.43$ & 8.00 \\
Tataru Fish Pond (TP) & $7.58-7.84$ & 7.70 \\
\hline
\end{tabular}

Recommended range* - 6.50-8.50

*According to WFD transposed into Order 161/2006 for the approval of the Normative concerning the classification of surface water quality to establish the ecological status of water bodies [10] 
Electrical conductivity (EC) results

EC values (Table 2) vary between locations, the highest average value being noticed for Branesti Fish Pond (1131 $\square \mathrm{S} / \mathrm{cm}$ ), and the lowest for Snagov Lake (499.19 $\square \mathrm{S} / \mathrm{cm}$ ). For Pantelimon II Lake other authors reported a value of 526 $\mu \mathrm{S} / \mathrm{cm}[3]$.
Usually, EC values of freshwater and pond water lie between 300-1200 $\square$ S/cm [16]. For aquaculture, the optimal range is 100$2000 \mu \mathrm{S} / \mathrm{cm}$ and some authors [20] reported that $\mathrm{EC}$ in fish ponds increases with the addition of fish food.

Table 2. EC values for water samples collected from lakes and fish ponds

\begin{tabular}{lcc}
\hline \multirow{2}{*}{ Location } & \multicolumn{2}{c}{$\mathrm{EC}, \mu \mathrm{S} / \mathrm{cm}$} \\
\cline { 2 - 3 } & Range & Average \\
\hline Cismigiu Lake (CL) & $784-841$ & 818 \\
Morii Lake (ML) & $412-1337$ & 734.2 \\
Pantelimon II Lake (PL) & $524-785$ & 653.5 \\
Snagov Lake (SL) & $483-530$ & 499.19 \\
Branesti Fish Pond (BP) & $1105-1156$ & 1131 \\
Tataru Fish Pond (TP) & $653-760$ & 696.42 \\
\hline
\end{tabular}

Total hardness $(\mathrm{TH})$ values

Average TH values (Table 3) are similar for Cismigiu Lake, Morii Lake, Pantelimon II Lake, and Branesti Fish Pond, meanwhile for Snagov Lake and Tataru Fish Pond are 2 and 2.6 times higher, respectively, but all values being within the desirable range for aquaculture (28-84 mg CaO/L) [18].

Some authors [21] stated that hard water lakes tend to produce more fish and aquatic plants than soft water lakes.

Table 3. TH values for water samples collected from lakes and fish ponds

\begin{tabular}{|c|c|c|c|}
\hline \multirow{2}{*}{ Location } & \multicolumn{2}{|c|}{$\mathrm{TH}, \mathrm{mg} \mathrm{CaO} / \mathrm{L}$} & \multirow{2}{*}{$\begin{array}{l}\text { Water classification } \\
(\mathrm{TH}, \mathrm{mg} \mathrm{CaO} / \mathrm{L})[21]\end{array}$} \\
\hline & Range & Average & \\
\hline Cismigiu Lake (CL) & $10.52-13.20$ & 12.08 & $<34$ - soft water \\
\hline Morii Lake (ML) & $5.70-32.46$ & 12.14 & 34.1-67 - moderately hard \\
\hline Pantelimon II Lake (PL) & $9.39-16.09$ & 12.85 & 67.1-100 - hard \\
\hline Snagov Lake (SL) & $24.12-28.61$ & 26.24 & $>100$ - very hard \\
\hline Branesti Fish Pond (BP) & $13.96-15.59$ & 14.75 & \\
\hline Tataru Fish Pond (TP) & $34.22-47.12$ & 39.76 & \\
\hline
\end{tabular}

Chemical oxygen demand (COD) results COD is an important tool to diagnose the organic pollution of the water and is expressed as the amount of oxygen that oxidizes organic species. Clean water usually has COD between 2-4 mg/L [22].

For investigated locations, the COD values (Table 4) are between 5 and $10 \mathrm{mg} \mathrm{O}_{2} / \mathrm{L}$, this range allowing framing the analyzed waters into second quality class for surface waters.

For Herastrau and Pantelimon lakes, other authors [23] reported COD values that allow framing the water from these locations in quality class II, as well. 
Table 4. COD values for water samples collected from lakes and fish ponds

\begin{tabular}{|c|c|c|c|c|c|}
\hline \multirow{2}{*}{ Location } & \multicolumn{2}{|c|}{$\mathrm{COD}, \mathrm{mg} \mathrm{O}_{2} / \mathrm{L}$} & & \multicolumn{2}{|c|}{${ }^{*}$ COD $\mathrm{mgO}_{2} / \mathrm{L}$} \\
\hline & Range & Average & \multirow[b]{2}{*}{$\mathbf{V}$} & & $>50$ \\
\hline Cismigiu Lake (CL) & $7.83-8.71$ & 8.15 & & & \multirow[b]{2}{*}{50} \\
\hline Morii Lake (ML) & $3.51-8.79$ & 5.78 & \multirow{3}{*}{ IV } & & \\
\hline Pantelimon II Lake (PL) & $3.89-6.35$ & 5.28 & & & \multirow[b]{2}{*}{20} \\
\hline Snagov Lake (SL) & $7.85-8.76$ & 8.45 & & & \\
\hline Branesti Fish Pond (BP) & $8.98-9.53$ & 9.27 & \multirow[t]{2}{*}{ III } & & \multirow[b]{2}{*}{10} \\
\hline Tataru Fish Pond (TP) & $7.99-9.58$ & 8.61 & & & \\
\hline \multicolumn{3}{|c|}{$\begin{array}{l}161 / 2006 \text { for the approval of the Normative concerning the } \\
\text { classification of surface water quality to establish the ecological } \\
\text { status of water bodies [10] }\end{array}$} & I & SL, BP, TP & 0 \\
\hline
\end{tabular}

\section{Results concerning nitrogen pollutant species}

In lakes, nitrogen appears as nitrite, nitrate, and ammonium ions, may come from fertilizers (synthetic or organic), wastes from septic systems, surface runoff, or groundwater sources, and all these forms may be used by aquatic plants and algae. A concentration higher than $0.3 \mathrm{mg} \mathrm{N} / \mathrm{L}$ in spring is sufficient to support summer algae bloom [21].
According to [6], high levels of ammonia, nitrate, and nitrite, derived from human activities may affect the ability of aquatic animals to survive, grow, and reproduce due to the toxicity of these species.

Based on nitrite levels, for the investigated locations are associated with quality classes II, III, and IV (Table 5).

Table 5. ${\mathrm{N}-\mathrm{NO}_{2}}^{-}$values for water samples collected from lakes and fish ponds

\begin{tabular}{|c|c|c|c|c|c|}
\hline \multirow{2}{*}{ Location } & \multicolumn{2}{|c|}{$\mathrm{N}-\mathrm{NO}_{2}^{-}, \mathrm{mg} \mathrm{N} / \mathrm{L}$} & \multicolumn{3}{|c|}{${ }^{*} \mathbf{N}-\mathrm{NO}_{2}^{-} \mathrm{mgN} / \mathrm{L}$} \\
\hline & Range & Average & \multirow[b]{2}{*}{$\mathbf{V}$} & & \multirow{2}{*}{$>0.3$} \\
\hline Cismigiu Lake (CL) & $0.014-0.019$ & 0.015 & & & \\
\hline Herastrau Lake (HL) & $0.023-0.066$ & 0.046 & \multirow[b]{2}{*}{ IV } & & \multirow[t]{2}{*}{0.3} \\
\hline Morii Lake (ML) & $0.010-0.207$ & 0.061 & & ML, BP & \\
\hline Pantelimon II Lake (PL) & $0.021-0.051$ & 0.033 & \multirow{3}{*}{ III } & & \multirow[t]{2}{*}{0.06} \\
\hline Snagov Lake (SL) & $0.010-0.046$ & 0.018 & & $\mathrm{HL}, \mathrm{PL}$ & \\
\hline Branesti Fish Pond (BP) & $0.068-0.078$ & 0.074 & & \multirow[b]{2}{*}{ CL, SL, TP } & $\mathbf{0 . 0 3}$ \\
\hline Tataru Fish Pond (TP) & $0.015-0.036$ & 0.023 & II & & 0.01 \\
\hline \multicolumn{3}{|c|}{$\begin{array}{l}161 / 2006 \text { for the approval of the Normative concerning the } \\
\text { classification of surface water quality to establish the ecological } \\
\text { status of water bodies [10] }\end{array}$} & I & & o \\
\hline
\end{tabular}

According to Durborow and collaborators [24], high nitrite levels may cause hypoxia due to methemoglobin formation in fish blood leading to "brown blood disease" manifestation. This situation seems to occur more likely in intensive culture systems.

Fish species present different sensitivities to nitrite levels. For example, largemouth and smallmouth bass, bluegill and green sunfish are resistant to high nitrite levels, catfish and tilapia are fairly sensitive, meanwhile trout is highly sensitive to a small amount of nitrite [24].

The highest nitrate level (4.54 mg N/L) was reported for Herastrau Lake, this value framing the water to III $^{\text {rd }}$ quality class (Table 6). Elevated nitrate levels for drinking water are of great concern for human health, due to methemoglobinemia occurrence, but in the case of fish, this is not as hazardous as we expect. For fish, nitrate is relatively non-toxic, excepting concentrations above $90 \mathrm{mg} \mathrm{N} / \mathrm{L}$ [18]. 
Table 6. $\mathrm{N}_{-\mathrm{NO}_{3}}{ }^{-}$values for water samples collected from lakes and fish ponds

\begin{tabular}{|c|c|c|c|c|c|}
\hline \multirow{2}{*}{ Location } & \multicolumn{2}{|c|}{$\mathrm{N}^{-\mathrm{NO}_{3}}{ }^{-}, \mathrm{mg} \mathrm{N} / \mathrm{L}$} & & \multicolumn{2}{|c|}{${ }^{*} \mathbf{N}-\mathrm{NO}_{3}{ }^{-} \mathrm{mgN} / \mathrm{L}$} \\
\hline & Range & Average & \multirow{2}{*}{$\mathbf{V}$} & & \multirow{2}{*}{$>11.2$} \\
\hline Cismigiu Lake (CL) & $0.37-0.47$ & 0.42 & & & \\
\hline Herastrau Lake (HL) & $2.27-6.29$ & 4.54 & & & \multirow[t]{2}{*}{11.2} \\
\hline Morii Lake (ML) & $0.51-3.39$ & 1.15 & \multirow[t]{2}{*}{ IV } & & \\
\hline Pantelimon II Lake (PL) & $0.11-1.47$ & 0.79 & & & \multirow[t]{2}{*}{5.6} \\
\hline Snagov Lake (SL) & $0.29-1.15$ & 0.55 & \multirow[t]{2}{*}{ III } & \multirow[t]{2}{*}{$\mathrm{HL}$} & \\
\hline Branesti Fish Pond (BP) & $1.83-2.13$ & 1.95 & & & \multirow[t]{2}{*}{3} \\
\hline Tataru Fish Pond (TP) & $0.14-1.24$ & 0.60 & II & ML, BP & \\
\hline \multicolumn{3}{|c|}{$\begin{array}{l}\text { *Quality classes according to WFD transposed into Order } \\
161 / 2006 \text { for the approval of the Normative concerning the } \\
\text { classification of surface water quality to establish the ecological } \\
\text { status of water bodies [10] }\end{array}$} & I & $\begin{array}{l}\text { CL, PL, } \\
\text { SL, TP }\end{array}$ & 1 \\
\hline
\end{tabular}

Usually, the term ammonia for lakes and ponds refers to a sum between unionized ammonia $\left(\mathrm{NH}_{3}\right)$ and ammonium ion $\left(\mathrm{NH}_{4}{ }^{+}\right)$and the proportion of these forms is affected by $\mathrm{pH}$ and temperature [25]. Unionized ammonia is very toxic to aquatic animals, mainly to fish species, and can cause toxicity to Nitrosomonas and Nitrobacter bacteria, inhibiting the nitrification process, which is also disturbed by increased levels of ammonium [6].

Ammonium levels range as an average between
0.21 and $4.39 \mathrm{mg} \mathrm{N} / \mathrm{L}$, the highest concentrations being encountered for Morii Lake and Branesti Fish Pond (Table 7) for which was attributed to the $\mathrm{V}^{\text {th }}$ quality class. Regarding fish life quality related to ammonia, the literature studies claim that toxicity varies with fish species. For example, salmonids are more sensitive than other fish species [26], meanwhile, goldfish, Carassius auratus, seems to have a greater resistance to ammonia [27].

Table 7. $\mathrm{N}_{-\mathrm{NH}_{4}}{ }^{+}$values for water samples collected from lakes and fish ponds

\begin{tabular}{|c|c|c|c|c|c|}
\hline \multirow{2}{*}{ Location } & \multicolumn{2}{|c|}{$\mathrm{N}-\mathrm{NH}_{4}{ }^{+}, \mathrm{mg} \mathrm{N} / \mathrm{L}$} & & \multicolumn{2}{|c|}{${ }^{*} \mathbf{N}-\mathrm{NH}_{4}{ }^{+} \mathrm{mgN} / \mathrm{L}$} \\
\hline & Range & Average & \multirow[b]{2}{*}{$\mathbf{V}$} & & \multirow{2}{*}{$>3.2$} \\
\hline Cismigiu Lake (CL) & $1.44-1.69$ & 1.58 & & ML, BP & \\
\hline Herastrau Lake (HL) & $1.71-2.85$ & 2.18 & & & \multirow[t]{2}{*}{3.2} \\
\hline Morii Lake (ML) & $0.43-6.81$ & 3.64 & \multirow[t]{2}{*}{ IV } & $\mathrm{CL}, \mathrm{HL}$ & \\
\hline Pantelimon II Lake (PL) & $0.13-0.31$ & 0.22 & & & \multirow[t]{2}{*}{1.2} \\
\hline Snagov Lake (SL) & $0.13-0.50$ & 0.21 & \multirow[t]{2}{*}{ III } & & \\
\hline Branesti Fish Pond (BP) & $4.28-4.50$ & 4.39 & & & 0.8 \\
\hline Tataru Fish Pond (TP) & $0.12-0.32$ & 0.21 & \multicolumn{2}{|l|}{ II } & \\
\hline \multicolumn{3}{|c|}{$\begin{array}{l}161 / 2006 \text { for the approval of the Normative concerning the } \\
\text { classification of surface water quality to establish the ecological } \\
\text { status of water bodies [10] }\end{array}$} & I & PL, SL, TP & 0.4 \\
\hline
\end{tabular}

Based on ammonium levels reported in other studies [23], water from Herastrau and Pantelimon lakes are framed in II quality class. According to nitrate and nitrite levels, reported by the same authors, for the same locations are attributed to quality classes I and IV, respectively.

In the case of Branesti Lake, for nitrite and ammonium, were reported elsewhere [28] lower values $(0.057 \mathrm{mg} \mathrm{N} / \mathrm{L}$ and $1.876 \mathrm{mg} \mathrm{N} / \mathrm{L}$, respectively), meanwhile for nitrate was found higher concentration (4.060 mg N/L).

\section{Phosphorus content}

The sources of phosphorus for aquatic systems are represented by waterfowl waste, plant

decomposition, fertilizers, industrial and domestic sewage. In surface waters, phosphorus 
occurs mainly as phosphate $\left(\mathrm{PO}_{4}{ }^{3-}\right)$ found in the concentration range $0.005-0.5 \mathrm{mg} \mathrm{P} / \mathrm{L}$ [18].

Phosphorus is an important nutrient but elevated concentrations lead to eutrophication, which consists of blooms of harmful algae, increased frequency of anoxic events, and death of aquatic organisms. Also, there are direct consequences on water quality, human/animal healthy, tourism, food/fishing industry [29].
Reported results indicated for Cismigiu Lake, Morii Lake, and Branesti Fish Pond levels below the detection limit (DL) of the used method for determination, this being consistent with the $I^{\text {st }}$ quality class for analyzed waters (Table 8).

For Snagov Lake and Tataru Fish Pond, phosphorus concentrations are high and allow framing to $\mathrm{V}^{\text {th }}$ quality class.

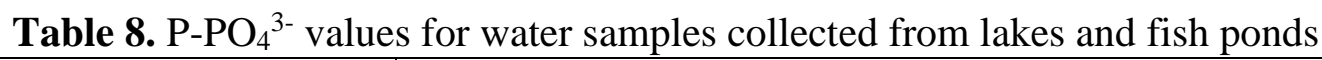

\begin{tabular}{|c|c|c|c|c|c|}
\hline \multirow{2}{*}{ Location } & \multicolumn{2}{|c|}{$\mathrm{P}_{-}-\mathrm{PO}_{4}{ }^{3-}, \mathrm{mg} \mathrm{P} / \mathrm{L}$} & & \multirow{2}{*}{\multicolumn{2}{|c|}{${ }^{*} \mathbf{P}-\mathrm{PO}_{4}{ }^{3-} \mathrm{mgP} / \mathrm{L}$}} \\
\hline & Range & Average & \multirow[b]{2}{*}{$\mathbf{v}$} & & \\
\hline Cismigiu Lake (CL) & $<\mathrm{DL}$ & $<\mathrm{DL}$ & & SL, TP & $>0$ \\
\hline Herastrau Lake (HL) & $0.28-0.49$ & 0.39 & & & \multirow[t]{2}{*}{0.9} \\
\hline Morii Lake (ML) & $<\mathrm{DL}$ & $<\mathrm{DL}$ & \multirow[t]{2}{*}{ IV } & $\mathrm{PL}$ & \\
\hline Pantelimon II Lake (PL) & $0.41-0.48$ & 0.44 & & & \multirow[t]{2}{*}{0.4} \\
\hline Snagov Lake (SL) & $0.73-1.93$ & 1.22 & \multirow[t]{2}{*}{ III } & $\mathrm{HL}$ & \\
\hline Branesti Fish Pond (BP) & $<\mathrm{DL}$ & $<\mathrm{DL}$ & & & \multirow[t]{2}{*}{0.2} \\
\hline Tataru Fish Pond (TP) & $1.13-2.20$ & 1.45 & \multicolumn{2}{|c|}{ II } & \\
\hline \multicolumn{3}{|c|}{$\begin{array}{l}161 / 2006 \text { for the approval of the Normative concerning the } \\
\text { classification of surface water quality to establish the ecological } \\
\text { status of water bodies [10] }\end{array}$} & I & CL, ML, BP & 0.1 \\
\hline
\end{tabular}

The level of phosphate phosphorus of 1.37 $\mathrm{mg} / \mathrm{L}$ and nitrate nitrogen of $1.47 \mathrm{~m} / \mathrm{L}$ produced a high density of euglenophytes, as reported by Rahman and Khan [30].

High phosphate levels were reported by other authors for Herastrau and Pantelimon lakes
[23].

Concerning the influence of phosphorus on fish life, Jespersen and co-workers [31] showed that the bodyweight of cyprinids decreases with the increase in phosphorus content of water samples.

\section{Comparative overview of quality classes}

A comparative evaluation of surface water quality for investigated locations related to quality classes is presented in Table 9.

Table 9. Comparative overview for surface water quality classes*

\begin{tabular}{l|ccccc}
\hline Location & $\mathrm{COD}$ & $\mathrm{N}^{-N_{2}}{ }^{-}$ & $\mathrm{N}^{-\mathrm{NO}_{3}}{ }^{-}$ & $\mathrm{N}^{-N_{4}}{ }^{+}$ & $\mathrm{P}_{-} \mathrm{PO}_{4}{ }^{3-}$ \\
\hline Cismigiu Lake (CL) & II & II & I & IV & I \\
Herastrau Lake (HL) & - & III & III & IV & III \\
Morii Lake (ML) & II & IV & II & V & I \\
Pantelimon II Lake (PL) & II & III & I & I & IV \\
Snagov Lake (SL) & II & II & I & I & V \\
Branesti Fish Pond (BP) & II & IV & II & V & I \\
Tataru Fish Pond (TP) & II & II & I & I & V \\
\hline
\end{tabular}

*Quality classes according to WFD transposed into Order 161/2006 for the approval of the Normative concerning the classification of surface water quality to establish the ecological status of water bodies [10]

\section{CONCLUSIONS}

Based on the presented results and after a comparative analysis, it is difficult to estimate which lake/fish pond has higher quality water since for each location at least one parameter 
frames the water in quality classes higher than III. Though, it could be assumed that waters from Snagov Lake and Tataru Fish Pond have higher quality due to one parameter $\left(\mathrm{P}-\mathrm{PO}_{4}{ }^{3-}\right)$ which allows framing to a quality class higher

\section{REFERENCES}

[1] YANG, X.E, WU, X., HAO, H.L., HE, Z.L., J. Zhejiang Univ. Sci. B., 9, no. 3, 2008, p. 197. doi:10.1631/jzus.B0710626.

[2] GHERVASE, L., IOJA, C., CARSTEA, E., SAVASTRU, D., $11^{\text {th }}$ Edition of the World Wide Workshop for Young Environmental Scientists (WWW-YES-2011) - Urban Waters: resource or risks?, Arcueil: France.

[3] IOJA, C., ONOSE, D., CUCU, A., GHERVASE, L., Energy, Environment, Ecosystems \& Sustainable Development, 2010, p. 164.

[4] MOROSANU, G.A., DONTU, S., COPACENARU, O., GAVRIL, V., ZAHARIA, F.-A., CARSTEA, E.M., $3^{\text {rd }}$ International Conference - Water resources and wetlands, 2014, Tulcea, Romania, p. 91; www.limnology.ro/wrw2016/proceedings.htm 1.

[5] WISNU, R.P., KARUNIASA, M., MOERSIDIK, S.S., Earth Environ. Sci., 399, 2019, doi:10.1088/1755-1315/399/1/012111.

[6] CAMARGO, J., ALONSO, A., Environ. Int., 32, 2006, p. 831.

[7] Narragansett Bay Estuary Program, 2017. State of Narragansett Bay and its Watershed, Chapter 18, Water Quality Conditions for Aquatic Life, p. 341.

[8] European Commission, Environment. Available from: https://ec.europa.eu/environment/water/waterframework/info/intro_en.htm [22.07.2020].

[9] Directive 2000/60/EC of the European Parliament and of the Council of 23 October 2000 establishing a framework for Community action in the field of water policy.

[10] Order 161/2006 for the approval of the Normative concerning the classification of surface water quality to establish the ecological status of water bodies.

[11] STAVRESCU-BEDIVAN, M.-M., SCAETEANU VASILE, G., MADJAR, R.M., MATEI, P.B., TOBĂ, G.F., AgroLife Scientific Journal, 4, no. 2, 2015, p. 132. than II. On the other hand, water from Herastrau Lake has the lowest quality, all parameters framing the water to classes III and IV.

[12] SCAETEANU, G., MANOLE, M.S., STAVRESCU-BEDIVAN, M.-M., PENESCU, A., PELE, M., Scientific Papers, Series E, Land Reclamation, Earth Observation \& Surveying, Environmental Engineering, 1, 2012, p. 113.

[13] STAVRESCU-BEDIVAN, M.-M., SCAETEANU VASILE, G., MADJAR, R.M., MANOLE, S.M., STAICU, A.C., AIOANEI, F.T., PLOP, E.F., TOBĂ, G.L., NICOLAE, C.G., Agriculture and Agricultural Science Procedia, 10, 2016, p. 328.

[14] STAVRESCU-BEDIVAN, M.-M., SCAETEANU VASILE, G., MADJAR, M.M., MANOLE, M.S., AgroLife Scientific Journal, 7, no. 1, 2018, p. 123.

[15] SCAETEANU VASILE, G., MADJAR, R.M., SILVESTRO, A., DULEA, C., STAVRESCU BEDIVAN, M.-M., International Multidisciplinary Scientific GeoConference SGEM 2018, Conference Proceedings, 18(1.5), p. 211, DOI 10.5593/sgem2018V/1.5/S02.026.

[16] SCAETEANU VASILE, G., MADJAR, R.M., SILVESTRO, A., DULEA, C., STAVRESCU-BEDIVAN, M.-M., International Multidisciplinary Scientific GeoConference SGEM Vienna Green 2019, Conference Proceedings, 19(1.4), p. 309, 10.5593/sgem $2019 \mathrm{~V} / 1.4 / \mathrm{S} 02.038$.

[17] LENNTECH. Available from: https://www.lenntech.com/aquatic/acidsalkalis.htm\#ixzz6QNe9eJ9i [02.07.2020].

[18] STONE, N., THOMFORDE, H., Aquaculture/Fisheries. Cooperative Extension Program, University of Arkansas at Pine Bluff. Available from: https://fisheries.tamu.edu/files/2013/09/Under standing-Your-Fish-Pond-Water-AnalysisReport.pdf [02.07.2020].

[19] Lavaris Lake. Available from: https://www.lavaris-lake.com/en/values-ofwater.html [02.07.2020]. 
[20] SCHENONE, N.F., VACKOVA, L., CIRELLI, A.F., Aquac. Int., 19, no. 5, 2011, p. 855.

[21] SHAW, B., MECHENICH, C., KLESSIG, L., Understanding Lake Data (G3582), RP-03, 2004.

[22] COHL, M., LAZĂR, L., BALASANIAN, I., Environ. Eng. Manag. J., 13, no. 9, 2014, p. 2301.

[23] IONESCU, P., RADU, V.-M., DIACU, E., MARCU, E., Adv. Eng. Forum, 13, 2015, p. 194, doi:10.4028/www.scientific.net/AEF.13.194.

[24] DURBOROW, R.M., CROSBY, D.M., BRUNSON, M.V., Nitrite in fish ponds. SRAC Publication No.462, 1997.

[25] The Fish Site. Available from: https://thefishsite.com/articles/managingammonia-in-fish-ponds [02.07.2020].

[26] STONE, N., SHELTON, J., HAGGARD, B., THOMFORDE, H., SRAC Publication no. 4606, 2013.
[27] SCHENONE, G., ARILLO, A., MARGIOCCO, C., MELODIA, F., MENSI, P., Ecotoxicol. Environ. Saf., 6, no.5, 1982, p. 479. [28] BENCIU, F., ENCIU, M., BUJOR, L., BOGAN, E., PUIA, O.-A., GABOR, S., International Journal of Academic Research in Environment and Geography, 4, no.1, 2017, p. 17.

[29] NGATIA, L. TAYLOR, R.,. Phosphorus Eutrophication and Mitigation Strategies, Phosphorus - Recovery and Recycling, Tao Zhang, IntechOpen, 2018, DOI: 10.5772/intechopen.79173. Available from: https://www.intechopen.com/books/phosphorus -recovery-and-recycling/phosphoruseutrophication-and-mitigation-strategies [02.07.2020].

[30] RAHMAN, M.M., KHAN, S., Bangladesh J.. Fish. Res., 11, no.1, 2007, p. 7.

[31] JEPPESEN, E., JENSEN, J.P., SONDERGAARD, M., LAURIDSEN, T., LANDKILDEHUS, F., Freshw. Biol., 45, 2000, p. 201. 